$12-31-2009$

\title{
Old Jokes and New Multiculturalisms: Continuity and Change in Vernacular Discourse on the Yucatec Maya Language
}

\author{
Fernando Armstrong-Fumero \\ Smith College, farmstro@smith.edu
}

Follow this and additional works at: https://scholarworks.smith.edu/ant_facpubs

Part of the Anthropology Commons

\author{
Recommended Citation \\ Armstrong-Fumero, Fernando, "Old Jokes and New Multiculturalisms: Continuity and Change in \\ Vernacular Discourse on the Yucatec Maya Language" (2009). Anthropology: Faculty Publications, Smith \\ College, Northampton, MA. \\ https://scholarworks.smith.edu/ant_facpubs/9
}

This Article has been accepted for inclusion in Anthropology: Faculty Publications by an authorized administrator of Smith ScholarWorks. For more information, please contact scholarworks@smith.edu 


\title{
Old Jokes and New Multiculturalisms: Continuity and Change in Vernacular Discourse on the Yucatec Maya Language
}

\begin{abstract}
Much recent literature on indigenous identity politics in Latin America has emphasized the emergence of new discourses on ethnic citizenship. However, the ways in which state-sponsored efforts to validate and revitalize the Yucatec Maya language become relevant to rural Yucatecans reflect far more continuity with older local narratives about the relationship between language use and modernity. Situating contemporary engagements with multicultural language policies within a broader history of locally meaningful language practices complicates the general model of indigenous language communities that has informed many recent studies of Latin American identity politics and reframes scholarly debates that have emphasized contrasts between emergent forms of essentialism or purism and more-traditional means of identity formation. This, in turn, suggests new routes through which multicultural and multilingual policies can be conceptualized for heterogeneous communities of indigenous language speakers. [Keywords: multiculturalism, language ideology, Maya, Mexico, Yucatan]
\end{abstract}

$\mathbf{T}$ HE POLITICIZATION of indigenous ethnic identity has played an especially visible role amid transformations in nationalism and notions of "citizenship" that have taken place in Latin America since the early 1990s (see Bartra 2002; Castañeda 1994; Garcia 2005; Hale 1994, 2005; Warren and Jackson 2002; Yashar 2005). Policies for the defense and promotion of indigenous peoples' rights to maintain their ethnic languages have been prominent both in national debates and in the scholarly literature related to these processes (see below). But in more than a decade of ethnographic research in Maya-speaking communities in the Mexican state of Yucatán, I have seen vernacular engagements with these "new" multiculturalisms that reflect a remarkable degree of historical continuity with several distinct, class-marked styles of speaking the Maya language that have been a part of the regional linguistic community since at least the 19th century. These continuities contrast with many of the iconic cases of post-Cold War indigenous identity politics, in which ideas of cultural and linguistic rights promote new forms of political subjectivity and grassroots constituencies. The case of Yucatán also provides insights into how local iterations of multicultural discourse are conditioned by deep-seated sociolinguistic hierarchies that exist within the Maya speech communities, a historical phenomenon that is an important counterexample to cases in which there seems to be a more clear-cut relationship between speaking an indigenous language and belonging to a clearly defined ethnic group and social class (French 2008; Gossen 1999:77-104; Graham 2002).

In some of the larger and more socioeconomically stratified communities in which I have conducted research, the diverse ways by which Maya speakers characterize their own relationship to their native language and to the broader social and cultural panorama of contemporary Mexico are especially striking. Wealthy handicrafts merchants and tourism professionals-the children and grandchildren of peasant agriculturalists-reproduce celebratory discourses on indigenous language with roots in the 19th century, positing an excision of Spanish borrowings and other external influences from the Maya language to assert their identity with a more-authentic "Maya culture." Poorer and less-educated neighbors-as well as those in smaller agricultural villages that are more isolated from major tourist sites-are less likely to use the Maya language to assert explicitly "Mayan" identities and are more likely to interact with the state through institutions in which they are interpolated as "peasants" or "agriculturalists." At the same time, these self-identified peasants often use a style of humor that 
focuses on contrasts between the sounds of Spanish and Maya to make fools of urban Spanish speakers-and even their better-off neighbors who have learned to "pass" in Hispanic society. Thus, they turn their own native mastery over Maya into a tool for a very different kind of social border maintenance.

As some recent authors have noted (Breglia 2006; Castañeda 2004; Castillo Cocom 2005; Gabbert 2004; Hervik 1999), the idea of a "Mayan identity politics" in Yucatán is often difficult to reconcile with the local heterogeneity that has contributed to these contrasting ways of inhabiting the Maya language. In particular, the association between speaking the Maya language and being entitled to certain rights as an indigenous person is far from clear in the vernacular speech of most communities. Contemporary forms of heteroglossia (Bakhtin 1982) attest to the much-longer history of social and linguistic diversity in the Yucatec Maya speech community. Although today it is the primary vernacular for members of a rural underclass that most foreigners and many urban Yucatecans characterize as "indigenous," the language has also been used extensively by persons who self-identified as the "white" descendants of Spanish conquerors and European immigrants. ${ }^{1}$ As is the case in the Nahuatl-Mexicano speech communities discussed by Jane Hill and Kenneth Hill (1986), how someone speaks Maya, and the metalinguistic discourses through which they justify their everyday linguistic choices, can be as dense an index of class, ethnic, and regional identities as the simple choice between Spanish and Maya.

Recent scholarship has provided a rich portrait of how post-Cold War multiculturalisms have brought about changes in metalinguistic discourses on Mayan languages in Mexico and Guatemala (Berkley 1998; Brody 2004; Brown 1996; England 2003; Fischer 1999; French 2008; Maxwell 1996), a process that parallels the experience of minority and postcolonial language communities in other regions of the world (Fishman 1985; Makihara 2004; Paulston 1997; Urla 1988; Woolard 1998; Woolard and Schieffelin 1994). In contrast, my own analysis of heteroglossia within the Yucatec Maya speech community provides a case in which the same kind of process takes on a very different local relevance. For example, metalinguistic practices that reflect the same kind of "essentialism" (Fischer 1999; Warren 1998) that is often associated with the latest iterations of indigenous language policy have played a role in Yucatec Maya language ideologies for well over a century, and their contemporary manifestations in vernacular speech cannot be seen as just an effect of changes in cultural policies that emerged in the last decades. Like the multifaceted relationship between speaking the Maya language and being a Maya person, this historical continuity has important implications for a comparative ethnography of the quotidian experiences that instantiate state-recognized identity politics in the lives of local communities.

The long history of heteroglossia within the socially diverse Yucatec Maya speech community makes the assess- ment of whether official cultural policies are promoting the emergence of new and empowering linguistic identities for rural Maya speakers especially complicated. A good example of this is an incident that I observed on an evening in the fall of 2004, when I watched a Maya-language television news broadcast with the family of a middle-aged woman whom I refer to as "Doña Benigna." Many people in the community identify Doña Benigna as a mestiza, a term that Yucatecans apply to women who wear traditional ethnic clothing and make extensive use of the Maya language. From conversations over the years, I know that her limited proficiency in spoken Spanish tends to compound her experiences of discrimination in hispanophone urban environments. She was, in this respect, a member of the disenfranchised population that was posited as the beneficiary of the multicultural policies that have led to the development of indigenous language media and intercultural education through the 1990s and that were formally incorporated into the Mexican constitution at the turn of the millennium. Like Doña Benigna, the newscaster on the television was a middle-aged woman wearing traditional clothes. She read her report-a narrative in which common Spanish borrowings were replaced with carefully wrought neologisms - from a piece of paper that she held before her. Linguistic purism is a common element of the writing used in state institutions and schools, which tend to treat code switching and lexical borrowing as a threat to the integrity and continuity of indigenous languages (see below). After a few minutes watching the newscast, Doña Benigna turned to me and said, in her more-colloquial Maya, "Letí le jach Mayajo,' máas(im)a'? M(a)in na'atikí" [That's that real Maya, isn't it? I don't understand it] (personal communication, March 8, 2004).

The fact that Doña Benigna perceived a degree of "otherness" in this state-sponsored inclusion of "her" language in mass media seemed consistent with the predictions of critical anthropologists who have argued that the latest wave of "official" multiculturalisms tend to make gestural concessions to ethnic rights but are ultimately articulated in ways that are less than advantageous to the communities that these policies were meant to serve (Bartra 2002; Hale 2005). However, if we account for the hierarchies that have existed within the heteroglossic field of Yucatec Maya speech since at least the 19th century, this seems less like an incident that was conditioned primarily by post-Cold War phenomena. The idea that there are "pure" forms of Maya that are completely autonomous from Spanish existed long before the multicultural policies that placed a Maya language newscast on Doña Benigna's television set; furthermore, many native speakers in Doña Benigna's home community continue to employ such purist forms to disassociate their own appropriations of the Maya language from negative stereotypes of indigenous poverty. This is not, however, the only means of turning this language into an expression of identity: many people, like Doña Benigna, often delight in using skillful wordplay that works at the 
interstices of Maya and Spanish to make fools of Spanish speakers or those who use the same purist register that she characterized as "real Maya." In this context, the success or failure of state-sponsored language promotion is not only one of creating an effective and inclusive standard but also a function of how these standards are instantiated amid the heteroglossic space in which speakers navigate between Spanish and Maya in different ways and to different ends.

If the equation between speaking an indigenous language and being an indigenous person is difficult to reconcile with the case of Yucatec Maya, a closer examination of the practices that Walter Mignolo has referred to as "languaging," or ways of "thinking and writing between languages" (Mignolo 2000:226), is especially useful (see also Garrett and Baquedano-Lopez 2002). I use this term to refer to the ways in which identities based on class, ethnicity, and territoriality can be indexed through word choice or explicitly stated through metalinguistic commentary on the relationship between multiple registers of Spanish and Maya. As Mignolo observes, this sort of linguistic performance tends to be predicated on the speaker's ability to move between registers and languages, rather than on the choice of inhabiting a single, autonomous linguistic code. ${ }^{2}$

As a heuristic device, I refer to two especially important local styles of languaging as "Imaginary" and "Deep" Maya, loosely adapting terms from Guillermo Bonfil Batalla's (1987) classic work on anthropology and Mexican nationalism. Bonfil argued that the image of a cohesive and monolithic national culture was an "Imaginary Mexico" that simplified a far-more-complex mosaic of the "Deep Mexico," which was represented by a myriad of indigenous, proletarian, and regional cultures. With the term Imaginary Maya, I refer to a style of languaging that tends to constitute "good" Maya as a speech form that is parallel to and yet autonomous from the dominant Spanish language. This style of language use and its concurrent metalinguistic discourses are characterized by the excision of calques, lexical borrowings, and other elements that disrupt the purity of an idealized language. The emphasis on purism, like its associations with educational elitism, contrasts with the form of languaging that I term Deep Maya. "Deep Maya" uses practices such as punning and code switching to exploit a range of phonological ambiguities that exist at the interstices of Spanish and Maya, constituting the speaker's distinctive identity through a certain style of humor and wit, rather than through speaking a "purer" form of the language. Just as Bonfil Batalla's "Deep Mexico" consisted of a series of subalternized local cultures that were excluded from the image of a monolithic national culture, the practices that I have referred to as "Deep Maya" are a self-conscious invocation of ambiguities that exist at the interstices of different languages or registers, disrupting their "purity" to poke fun at speakers of more-prestigious forms. In the following sections, I provide a historical and ethnographic sketch of these two styles of languaging before entering into a discussion of how this heteroglossic vernacular substrate influences the local experience of official multicultural discourses today.

\section{DEEP MAYA AND HUMOR}

The languaging practices that I have referred to as "Deep Maya" are a common aspect of forms of humor that permeate everyday encounters between native speakers and class or ethnic "outsiders," and they index a range of hierarchized social identities. Whether these practices are used to contrast Spanish to Maya or colloquial uses of Maya to the more-purified form of the indigenous language that figures in official promotion, they turn forms of speech that are associated with traditionally stigmatized class and social identities into a weapon that can be used in everyday encounters with ethnic and class outsiders. The styles of languaging that I characterize as "Deep Maya" tends to be associated with members of a rural underclass with stronger ties to specific rural communities (referred to as kajo'ob in Maya), rather than to the region's traditional centers of urban culture. Many people in these communities self-identify as mayeros or mayeras, a term that refers to their preference for Maya language in everyday interactions. The fact that this preference can index additional elements of class identity is evident in the fact that many mayeras and mayeros also traditionally self-identified as maasewalo'ob or otsil mako'ob (two Maya terms that can be translated as a "poor people" or "humble people"). Spanish terms that are commonly applied to people from the same communities include the class label campesino (Sp. peasant) and the ethnonym mestizo, which in Yucatán refers to rural Maya speakers who wear traditional clothes. ${ }^{3}$ In the often-contentious interactions between rural and urban people, mayeros also find themselves labeled with ethnic slurs like índio (Sp. Indian, always pejorative in Yucatán) and güiro (lit., "gourd," which used in this context is roughly translated as "hick").

Like the "whiteman" in the Apache joking tradition studied by Keith Basso (1979) or uses of "mock Spanish" that Jane Hill documented among Anglo-Americans (1998a), Deep Maya humor tends to articulate the identity of rural mayeros and mayeras through their interaction with a social and linguistic "other" referred to as ts'ul (males) or xunam (females). Although these social categories are associated with fluency in Spanish, they do not necessarily exclude people who speak Maya. The terms $t s^{\prime} u l$ and xunam are used to refer to urbanites and foreigners who are associated with hispanophone culture. But they are also applied to people raised in Maya-speaking families who attain enough education and wealth to "pass" in urban settings. In these cases, it does not denote a clear-cut transition into a non-Indigenous Hispanic ethnic group so much as class pretentions that distance rural parvenus from the realities of neighbors in their native kaj communities. In many stories, the "new" ts'ul or xunam is represented as someone whose native knowledge of Maya has grown rusty, making it likely that they will be outwitted in "Deep Maya" 
linguistic play that serves as a form of border maintenance for rural communities (Burns 1983).

Where the style of in-group humor described by Basso focused on the imitation of "whitemen's" manners, the punch line of "Deep Maya" mockery of ts'ulo'ob (plural of $t s^{\prime} u l$ ) entails a more explicitly metalinguistic commentary on phonological ambiguity that occurs in Spanish-Maya dialogues and assumes a kind of linguistic mastery and wit that are highly valued in rural Yucatán. Jokes in Yucatec Maya are most often based on puns and double entendre (see Burns 1983), mirroring common uses of punning in more-spontaneous humorous performances through quips that invert the meaning of a speaker's statement. As I learned Maya, I found that these spontaneous word games were a constant form of hazing to which I was subjected by friends and consultants. I have heard a number of women take advantage of puns in this way, but it is likely that my own experience as a male ethnographer created many situations in which the racy banter of masculine sociability became the backdrop for competitive joking in which a skillfully placed double entendre can turn an interlocutor into the butt of collective laughter. Thus, like other ts'ul ethnographers who learn Maya while being fluent in the more socially prestigious Spanish language (see Castañeda 1996), my experience as the butt of Deep Maya humor occurred in social situations in which my interlocutors used their mastery of a less-prestigious speech form to level my class and ethnic privilege.

That these incidents are considered highly humorous is evident in the fact that they are often recounted after the fact as story narratives built around a formal punch line. I discuss two such stories that I recorded over the course of interviews or copied in my field notes after more-spontaneous conversations. The tellers of these stories all claimed that they were based on real events, although they might have been fictional accounts composed by the storyteller. I later shared these stories with native Maya speakers to double check the phonetic bases of some of the puns, and both elicited laughter on subsequent tellings. In the quoted sections below, I have stressed the specific phonological components that serve as punch lines for the stories.

In the community of Xcalakoop, I was told of an incident that involved an anthropologist from Mérida who lived there decades ago. Every day, the ts'ul would follow villagers into the milpa (swidden field) and observe how they worked. One day, as he shared the peasants' meal of boiled beans, he found an object that he assumed to be a piece of green squash in his bowl. As he proceeded to eat it, a boy noticed that a much (Ma. a type of frog) had leaped to its death into the boiling pot of beans and shouted, "Ts'ul, le ba'al ka jaantik much!" [Ma. Ts'ul, that thing that you are eating is a much!]. Only partially understanding the Maya phrase, the anthropologist shook his head ruefully, looked into his bowl, replied in Spanish, "Es mucho para tí pero muy poco para mi" [Sp. It is much for you but very little for me], and finished eating his frog.
In a similar joke, this one about a gringo tourist and his monolingual Mayan hostess from Pisté, the ts'ul misses his meal. As the story goes, the tourist entered a home in which the lady of the house was preparing a broth of squash blossoms (Ma. $\mathrm{Lol}$ ). Wiping the sweat from his brow, he shouted, "Mucha Calol!" [Sp., pronounced with a thick English accent; It's very hot!]. Minutes later, when he asked about lunch, the nojoch maama (old mother, matriarch) tells him that it had been thrown out. When he complains, she replies, "Pero, ka k'uchech ta wa'alaj 'm[a] u cha'akal lol!'” [Ma. But, when you arrived, you said "one does not boil squash blossoms!"].

When I heard these stories for the first time, my own laughter was conditioned by the memory of the process through which I became the butt of incidents similar to those recounted. Fictional or not, the stories of the frogeating anthropologist or the overheated and hungry tourist are fairly accurate portrayals of the more-spontaneous linguistic games that take place in everyday life. A good example from my own fieldwork occurred one night as I sat with some friends in the town of Pisté. I was asked what the Maya word for moon was. Innocently, I replied with the obsolete term $u j$. The friend who asked me laughed and expressed amazement at my esoteric knowledge of a long forgotten word. He continued, "To'oné, k a['al]ik lúunaj" [Ma. We say lúunaj (a borrowing from the Spanish, luna)]. He pointed to the moon and said what I initially took to be "Letí jump'el luunaj" [Ma. that one is one luna]. I repeated what I thought he had said while pointing at the moon and nodded in agreement. I only realized the joke at my expense as the others started laughing. My friend repeated what he had just said more slowly, making it clear that he had intentionally mispronounced the sentence by saying "Leti' un pel u na" [mixed Ma. and Sp.; "that one is a vagina-of-his-mother's" (a common insult)].

This particular linguistic game demonstrates how these humorous power struggles occur not only at the interstices of Spanish and Maya but also amid the heteroglossia that exists within ostensibly Maya-language interactions. The joke at my expense was a reference to the elitist urban culture that is associated with the forms of languaging that I refer to as "Imaginary Maya." The feigned surprise at my knowing the "ancient" word for moon reflects a common assertion that the rural people of Yucatán no longer speak the "real" Maya (Ma. jach maaya) and that this is the purview of book-learned outsiders. But where I won the first round of the game by unexpectedly producing an obsolete term from my book learning of the language, my interlocutor successfully tricked me into following him into a register in which I was helpless.

It is possible to trace Deep Maya linguistic play and its use in social boundary maintenance through earlier periods in the history of Yucatán. The Anglo-American adventurer John Lloyd Stephens recorded an incident that took place in the early 1840s when he visited the fiesta in the town of Ticul. A local pig butcher greeted the foreigner with a "loud 
harangue" in Maya, much to the amusement of the crowd (Stephens 1963:66). An even older and more-detailed example of this humorous linguistic aggression can be found in the writing of Fray Pedro Beltrán, a priest born and raised in Yucatán in the early 18th century. Although he himself was a creole closely identified with hispanophone culture, he chose to pen a critique of the shortcomings of the more-prestigious Spanish-born priests with a typically Deep Maya form of humor. He described a series of scandalousalthough doubtlessly hilarious-misapprehensions of sermons that occurred when the linguistically inept Spaniards confused " $\mathrm{C}$ " and " $\mathrm{K}$ " sounds (nonglottalized and glotallized velar plosives, written $\mathrm{k}$ and $\mathrm{k}^{\prime}$ respectively in the contemporary orthography). ${ }^{4}$ So, for example, by saying "ocolneneex bey u yoocol Magdalena" versus "okolneneex bey u yookol -Magdalena"-substituting a nonglottalized velar plosive for the glottalized-a linguistically inept priest inadvertently said, "You should steal as Mary Magdalene stole" instead of "You should cry as Mary Magdalene cried" (see Barrera Vasquez 1980).

As in the ethnographic and historical examples above, Beltrán and the pig butcher of Ticul use phonetic elements that are confusing to less-proficient speakers to turn a potential source of stigma-use of Maya, rather than Spanish, English, or other "civilized" languages-into a weapon. The fact that similar incidents take place with anthropologists and tourists today is a testament to the long history of these Deep Maya practices as a means of articulating linguistic identity by turning persons associated with moreprestigious speech forms into the butt of humor. In all of these cases, it is not the use of Maya instead of Spanish that is the crux of the identity expressed through Deep Maya practices but, rather, the way in which the mayero's wit can exploit the ambiguities that emerge in dialogue between the two languages. This is the principal contrast between these languaging practices and those that I refer to as Imaginary Maya, another part of the heteroglossic substrate of contemporary engagements with multicultural discourse that is the focus of the next section.

\section{WRITING AND IMAGINARY MAYA}

Where Deep Maya practices draw on forms of humor associated with oral dialogues and language games, the languaging practices that I have referred to as "Imaginary Maya" are closely related to the technology of alphabetic writing and European notions of "grammar" and "lexicon." The introduction of Latin alphabet writing to the Maya language in the 16th century was not only a new technology for representing the sounds of speech (Mignolo 1995) but also the beginning of a process that instituted a range of new metalinguistic tools that are evident in the dozens of dictionaries, grammars, and didactic texts written about Maya by Spanish clerics in the 16th and 17th centuries alone (Carrillo y Ancona 1950). Through the training of indigenous scribes by Spanish clerics, this scholarly production dovetailed with a vernacular tradition of Maya-language writing in genres that ranged from religious texts to land titles, notarial documents, and letters. These texts were written and read in many rural Yucatecan communities from the 16th until well into the 20th century (Restall 1997; Sullivan 1989). ${ }^{5}$ As Anthony Berkley (1998) has noted, the concatenation of scholarly texts like grammars and dictionaries with vernacular writing traditions in the colonial period also marks the beginning of the process of creating "purist" forms of Maya that were distinct from everyday speech (see also Durbin 1969; Hanks 1986). Here, I situate Maya language writing and purism within a broader practices that I refer to as Imaginary Maya, a concatenation of performances and metalinguistic commentary that has broader sociolinguistic implications amid the hierarchies and heteroglossia that exist within the Maya language community.

Berkley (1998) observed how the proscriptive grammars and formal dictionaries written by Spanish clerics in the 16th to 18th centuries imposed Latinate standards that were foreign to native uses of language to writing and teaching in Maya (see also Brody 2004). As part of the more-generalized metalinguistic discourse that I call "Imaginary Maya," this disjuncture between spoken and written forms of the language acquired some of its central ideological elements after Yucatán's independence from Spain, particularly in the period between the 1840s and 1870s. During this period, philological and antiquarian studies by foreigners and members of a native-born creole (Eurodescendant) elite emerged as a basis for later expressions of regional identity and for the development of international Mesoamerican studies (Carrillo y Ancona 1950; Chuchiak 1997; Cifuentes 2002). Through this tradition, urban Yucatecans referred to their adoption of "philosophical" and "enlightened" perspectives as a way of participating in a larger trans-Atlantic intellectual community. Steeped in the moral and aesthetic ideals of Romanticism, this was an intellectual climate that emphasized hierarchies between "civilized" and "primitive" languages and that posited unified forms of speech as a fundamental element of the consolidation of strong and enlightened nation-states.

In early modern Europe, the creation of "high" registers of language and the promotion of unified vernaculars emerged as parallel processes. The nationalist philology that inspired Yucatecan romantics deployed two interrelated gestures: the formulation of specialized intellectual languages that were detached from the errors of "traditional" speech and narrative (Bauman and Briggs 2003) and the transformation of these "enlightened" vernaculars into the basis for unity and psychic progress within the language community (Bendix 1997; Gal 2001). The heritage of this language ideology motivated the one-to-one correspondence between language use and group membership that is still evident in multicultural models of indigenous ethnicity (French 2008; Graham 2002; see also Silverstein 2000). 
These processes of "civilizing" language and celebrating national identity represented a particular double-bind for elite yucatecos (people from the state of Yucatán), as it did for the authors of other Romantic indigenisms in Mexico and Latin America (Bonfil Batalla 1987; Keen 1971; Villoro 1950). Although indigenous languages offered a basis for articulating a distinctly "national" identity after independence from Spain, they were also a reminder of the fact that members of this elite were closer geographically and often socially to indigenous people than they were to the citizens of "civilized" nations of Europe. This double bind was addressed by a bifurcated strategy of validation and distancing that, even today, is a common feature of Imaginary Maya languaging.

For many members of the 19th-century Yucatecan elite, as for many of the first foreign scholars to study Mesoamerican languages (see, esp., Brinton 1890; Silverstein 2000), the value of different languages could be measured in terms of an equation between grammatical structures and mental processes (see also Humboldt 1988). In texts written by hispanophone Yucatecans in the decades that followed independence from Spain in 1821-23, there is an evident tendency toward more-favorable evaluations of Maya language and the mental patterns that it conditioned, something consistent with its validation as a source of postcolonial "national" identity. Writing in the last years of Spanish domination, the curate of the town of Yaxcabá noted, "The Maya language is very poor in terms for intellectual or spiritual things, and abundant in the mechanical and the material" (Granados y Baeza 1845). By the 1850s, two decades after independence, a municipal officer named Juan Pio Perez would make a far-more-generous argument for the expressive potentials of Maya, shifting the blame for the incomprehension of religious concepts to Hispanic translators that were:

\begin{abstract}
servile [translators] of hyperbole and allegory in the Castilian and Latin languages ... forms of saying that cannot be generalized among the Indians, as [they are] distinct to those demanded by the genius of their language. There are some figures of Castilian that could not be translated into their language without ridiculousness, like [saying] Most High for God. They would say [as] equivalent "beautiful lord," as it is very common to hear Cichcelem yun [sic]. All [this] ends up being the same with different words, and the good translator must be up on all of these that appear as little things but which are substantial when one tries to speak in a language and in its national usage. [Carrillo y Ancona 1950:164]
\end{abstract}

But is this reference to the "national usage" of the Maya language a reference to the speech of the domestic and agricultural workers with which members of the elite were in daily contact? Given the persistent stigma on Maya as a language of "Indians," establishing different forms of distance from the Maya language was an important secondary gesture for the Yucatecan romantics. This distance was provided, in part, by the notions of authenticity built into Romantic philological traditions, which posited vocabulary borrowed from other languages as an extraneous feature that degenerated the original "national" form of languages (Humboldt 1988). This immediately disqualified the language of the indigenous-identified underclass, whose speech had already been transformed by extensive contact with Spanish speakers. One Yucatecan antiquarian suggested that those interested in the history of the language should visit villages far from the coast, where men still had long hair and wore the traditional loincloth and where the people spoke a tongue somewhat distinct from the more-familiar Maya of Mérida and surrounding haciendas, writing "given that civility has not advanced there, they remain in the habits they have taken from their ancestors" (Hernandez 1841:271).

Reproducing classic conventions that have equated spatial with temporal distance (Fabian 1983), the idea that an "unspoiled" version of the Maya language existed somewhere just beyond the reaches of "civilization" becomes a cornerstone of Yucatecan romanticism. This not only deauthorizes the Maya spoken on a daily basis by creoles, hacienda workers, and urban artisans but also situates the true genius of the language outside of the systems of economic exploitation that brought elite intellectuals into everyday contact with the monolingual Maya-speaking lower classes. This romantic image of a Maya culture and language existing in a timeless externality to modernity would be a mainstay of a long regional tradition of indigenous-themed narrative produced for Hispanic-identified readers (Mediz Bolio 1934), and it parallels the constitution of "folk" societies in romantic nationalisms (Bendix 1997).

This literary iteration of Imaginary Maya discourse has been, for much of its history, a genre written by and for members of a regional elite that identified with urban hispanophone culture. It was not until the last third of the 20th century that explicitly literary Maya language writing developed as a locus of enunciation for writers whose class and ethnic origins are tied to rural communities. A literary sphere for authors with a strong class and ethnic identity with rural communities was further politicized with the critiques of Mexico's institutional anthropology and assimilationist cultural politics in the 1970s and 1980s (see Bonfil Batalla 1987; Warman 1967). Educated Maya speakers found new sources of employment and opportunities for activism in a new generation of state-sponsored educational and multicultural institutions as well as in an emerging NGO sector (Berkley 1998). By the 1990s, Maya language writing had a far stronger presence in public school curricula and in a number of state-sponsored publishing initiatives. The printing and distribution of these texts has been fraught with budgetary constraints imposed by agencies for whom indigenous language publication is a relatively low priority, and emergent independent media in Yucatec Maya have struggled to establish long-term continuity. Still, state-sponsored publications and civil-society groups have contributed to the development of a significant 
readership among educated native speakers, many of whom work within public education institutions and media that diffuse Maya language writing and associated metalinguistic discourses to local communities (Brody 2004; Hoil Gutierrez et al. 2008).

Still, the ways in which the Maya language is imagined within these newer literary genres and multicultural institutions have a number of significant continuities with elements of Imaginary Maya that emerged in the mid-19th century and that have historically been used to inscribe social hierarchies. The most significant of these is the tendency to treat code-switching and Spanish borrowings as a threat to the continuity of the language. Maya language authors tend to excise common borrowings from their writing, using less-common Maya terms, reviving obsolete usages, and using neologisms. For example, where the use of the Spanish term pero ("but") is common in vernacular speech, many authors use the less-common Maya term chen ba'ale' (roughly, "the thing is"). This practice is common in creative literature and is also present in the translations of laws and government communications that are mandated by current multilingual laws. Thus, a translation of the federal law of linguistic rights translates "Federal Government of Mexico" as u jaalachil noj lu'um méejiko (Ma. lit, "The rulership of the great land of Mexico), a term that would be utterly unfamiliar even to monolingual Maya speakers, most, if not all, of whom have grown up using the Spanish borrowing féederasion or péederasion. ${ }^{6}$

Just as they did in the 19 th century, contemporary metalinguistic narratives that are framed in the purist logic of Imaginary Maya tend to constitute the more-dynamic relationship between Spanish and English that is at the core of Deep Maya metalinguistic practices as a negative influence on the continuity of the language. But, even if someone like Doña Benigna might not consider the language posited by these practices to be "hers," there are many rural Maya speakers who are drawing inspiration from this particular style of languaging. Their relationship to emergent discourses on language rights, and to Deep Maya languaging, is the focus of the next section.

\section{SOCIAL STATUS AND VERNACULAR MULTICULTURALISM}

The municipalities of Tinúm and Chan Kom, where I have conducted ethnographic research since 1997, exemplify the socioeconomic diversity of contemporary Maya speakers and the heteroglossic context in which different ways of languaging Maya come into play today. Some communities in these municipalities experienced dramatic growth with the expansion of the tourist trade after the 1970s (Castañeda 1996), a phenomenon that has both amplified older social hierarchies and created new potentials for advancement or marginalization. Interviews that I have conducted with members of an emergent middle class in Pisté and Xcalakoop, communities with privileged geographical access to major tourist sites, provide important insights into exactly where recent iterations of Imaginary Maya discourse are being incorporated into the vernacular speech of some social strata in these communities. I use the term middle class to refer to generally well-educated families whose members work as wage earners in the tourist industry, in food service, as tour guides, or as retail merchants of handicrafts. These families are well-off by local standards and do not engage in subsistence agriculture or traditional manual trades like construction or handicrafts production. Many of the individuals who have seemed most receptive to the discourse of official language promotion emerge from within this group, even if families that produce agriculturalists and unskilled workers tend to make far-more-extensive use of the Maya language in everyday life. In this sense, members of the local middle class express attitudes about language that diverge significantly from classic models of "ladinoization" in Mesoamerica, which posit a unidirectional process by which better-off indigenous language speakers abandon traditional language, dress, and occupation and assume a new identity as assimilated members of a "national society" (Bonfil Batalla 1987). At the same time, many of the ways in which better-off Maya speakers in these communities embrace contemporary forms of Maya language promotion also run counter to the assumptions and stated goals of official multiculturalisms that are promoted as a form of subaltern politics.

Given the development of cultural tourism and the emergence of multicultural policies, contemporary iterations of Imaginary Maya discourse seem to derive some of their local relevance from the tangible political and economic potentials of Maya identity. However, because of the emphasis on poverty alleviation in most of the programs available for "indigenous" development in Mexico, the presence of formal multicultural institutions has been limited in communities like Pisté and Xcalakoop. In spite of well-publicized efforts to develop more-inclusive school curricula, the actual reach of bilingual education programs in Yucatán has also been limited: at least two-thirds of students in Maya-speaking communities attend exclusively Spanish-medium schools (Pfeiler and Zámisiá 2006). Although smaller and more-isolated communities in the municipalities of Chan Kom and Tinúm-neighbors of larger, wealthier communities like Pisté and Xcalakoop—have primary schools that make extensive use of Maya, curricula in the larger towns are overwhelmingly composed of Spanishmedium education.

Given the lack of formal state-sponsored multicultural institutions in these larger communities, Maya speakers in communities like Pisté and Xcalakoop most often encounter the discourse of multiculturalism and language rights through mass media-like the newscast that I saw with Doña Benigna-or in short-term programs run by local groups, such as workshops in which members of religious congregations produce Maya-language texts for their missions in more-monolingual communities. One result 
of this rather-spotty institutional presence is that many key aspects of official multicultural policy and philosophy remain relatively ambiguous for local nonexperts. Bambi Schieffelin's observations about the language ideologies associated with emergent literacy among the Kaluli of Papua New Guinea also applies to everyday encounters in which the ultimate rationale of multicultural discourse on the Maya language is "often implicit, unarticulated, or out of awareness" (Schieffelin 2000:311).

One fairly consistent aspect of vernacular iterations of "Imaginary Maya" discourse that I have encountered in the communities in which I have conducted research is a narrative about the loss or decay of Maya (see also Berkley 1998). This is, in some senses, an accurate perception of a language shift taking place in the wealthier communities like Pisté and Xcalakoop, where there is a marked tendency for young children of all but the poorest families to speak more Spanish than Maya. However, this narrative of loss tends to refer as much to local perceptions of the nature of "modernization" as it does to the local inequalities that are actually conditioning language choice. Many people cite the change or loss of certain Maya terms, such as the observation that low benches called $k^{\prime}$ anche today were known as kisiché (lit., "the wood you fart on") by earlier generations. Others point to the presence of Spanish borrowings like pero (but) or entonces (and then) in Maya as evidence of how the language "has become mixed" (Sp. Ya se mezclo, Ma. Ts'u xek'tal; personal communication, July 21, 2003). Interestingly, there is evidence that many of these Spanish borrowings have been common in Yucatec Maya since the 18th century (Lockhart 1999:213). However, vernacular narratives about "loss" make few distinctions between different processes of language change, positing a generalized process of linguistic decline.

These vernacular narratives about the "loss" of Maya often employ an equation of space and time that replicates the "distancing" effect popularized by the creole philologists of the mid-19th century. People that I've interviewed in Pisté or Xcalakoop are quick to point out that their own Maya is "mixed" and suggest that some of the moreisolated peasant villages where I have also conducted research speak a less-"mixed" form of Maya. Perhaps ironically, it is in these marginal hamlets where I have had some of my most befuddling experiences as the butt of linguistically hybrid Deep Maya humor. But many middleclass speakers associate linguistic purity with other rural habits that they themselves abandoned through the adoption of more-"modern" bourgeois lifestyles, echoing a common tendency to articulate modern identity as nostalgia for the past (Appadurai 1996; Williams 1973). Like the narratives about the loss of "respect" that Hill (1998b) documented among Nahuatl speakers in central Mexico, nostalgia for the "loss" of an Imaginary Maya and other forms of traditional life often tends to reference a series of contemporary inequalities within indigenous-language communities.
One explanation that is often offered for the loss of the word kisiche' is a good example of the classist undertones of linguistic nostalgia. The "wood you fart on" is the traditional seat used during simple peasant meals eaten around a collective plate of food into which family members dipped their tortillas. The posture that it enforced placed the sitter's body into a position well-suited for good digestion and intestinal movement. This is an experience unfamiliar to younger people accustomed to eating once-exotic foods in individual portions off of urban-style furniture and with forks and knives. In this case, the loss of the term also denotes self-consciously modern transformations in household accoutrements, foods, and body discipline that are still associated with the agrarian underclass living in moremarginal communities.

Contemporary hierarchies are also inscribed onto metalinguistic discourse in other ways. Many people's narratives about the "loss" of Maya also tend to replicate the deauthorization of actually-spoken Maya promoted by $\mathrm{Yu}$ catecan creoles in the mid-19th century. For many people that I have interviewed, there is some ambiguity as to whether the language that deserves special protection and promotion is the common speech of streets and swidden fields or if it is something that must be cultivated through book learning and other specialized forms of knowledge. A 40-year-old butcher and handicrafts merchant that I interviewed in Pisté observed that:

And thanks to what the anthropologists say, we know that Maya is important. Now we know that it is important and that it has grammar. Not like before, when it was said that it was a [only a primitive] dialect. We know now that it is important to preserve, because Maya is being lost. The way we speak it has become very mixed. [personal communication, August 2, 2003]

In this case, scholarly interest is credited with reversing a traditional racist discourse that dismisses indigenous languages as mere "dialects" that lack the nuance of "languages" like Spanish and English. But at the same time, this statement deauthorizes the vernacular speech of Pisté people as "mixed" and as an index of the "loss" of Maya. In effect, it posits the "important" language that "has grammar" as an Imaginary Maya that will only be accessible to rural speakers through special efforts but that has apparently been well-studied by nonlocal experts.

I have encountered similar statements that concurrently validate the Maya language and deauthorize native speakers in a number of everyday contexts in rural communities. Like many other researchers, I have had the experience of being qualified as an expert in "older" forms of Maya that can be learned in books, in spite of the very obvious limitations to my ability for nuanced expression in the language. A fairly typical example is when a handicrafts merchant in his fifties expressed his amazement at the fact that I knew the names of Maya numerals up to ten (nearly all Maya speakers switch to Spanish numbers after "four"). 
He said: "You're very clever. I'm an indio [a pejorative term translated literally as "Indian"] and I didn't know that." He made me repeat the numbers several times, listening carefully until he could repeat them verbatim, then said: "Now I've learned something of the old Maya!" (personal communication, July 15, 2002).

I understood his reference to himself with the pejorative term indio as a gentle dig at my book learning, not entirely unlike the night that I was made to swear at the moon. My flaunting of esoteric knowledge might seem to constitute him as an indio, as one who lacks the kind of education that turns foreigners with limited fluency into "experts" in real Maya, but he is also an indio insofar as he is someone with a Maya surname who uses the language far more expertly than I do. Still, it is probably precisely my status as an exotic, well-educated person who learned Maya as a third language that imbued my knowledge of numbers with the kind of Imaginary Maya authority that made it a credible example of "old" Maya.

Writing is another feature that grants authority to Maya usages that are part of official promotion efforts but unfamiliar to native speakers. As I noted earlier, the neologisms, obsolete lexical items, and archaic word forms used by many contemporary Maya language authors are unfamiliar to most native speakers. But, in a phenomenon that has been documented in standardization projects for other languages (Jaffe 1996; Schieffelin and Doucet 1994), those who choose to recognize this written standard often assume that it trumps the spoken word (see also Berkley 1998; Brody 2004). For example, I interviewed a 40-year-old minister participating in a Maya-writing workshop sponsored by a protestant congregation in Pisté who observed: "Before I learned this alphabet, I used to pronounce the word paax for music with the short ' $a$ ' like pax. But now I know that it is paax" (personal communication, August $11,2004)$. What was interesting in this case was that this man, like other participants in the workshop, was a native of an eastern microregion where people are known to speak Maya with a clipped accent, using many contractions. But in his statement, he shows that the "literary" forms that could be learned in special courses or workshops clearly trumped the Maya spoken in the streets and swidden fields.

Just as bilingual creoles in the 19th century used Imaginary Maya as a way to celebrate the "national" language of their home region while distancing themselves from the native speech of the rural poor, the public performance of a language that is distinct from the common vernacular seems to be attractive to members of social classes who would otherwise tend to embrace hispanophone culture. A class-marked identity with an Imaginary Maya is in many ways analogous to the "linguistic terrorism" employed by urbanized, upwardly mobile Nahuatl speakers to their village-bound kinsfolk, as documented by Hill (1985). Over the years, I have noticed that middle-class native speakers of Maya who are equally comfortable in Spanish are more likely to engage in the linguistic performance of excising Spanish borrowings from common Maya phrases. One of the most frequent of such performances concerns the Maya equivalent of "thank you." For a monolingual peasant, this term is uttered as "Dios bo'otik" [Ma. God will pay you]. Many bilingual, well-educated Maya speakers have corrected my use of this phrase with Yuum bo'otik (Ma. The Lord / Owner will pay you), a term that is rarely, if ever, used in speech between native speakers. In some of the more-extreme cases, identities articulated through speaking a prestigious Imaginary Maya can reproduce the same Hispanocentric language ideologies that qualified Spanish as a "language" and dismissed Maya as a primitive "dialect." For example, I interviewed a man in his mid-fifties-a prosperous grocery merchant from Pisté-regarding a series of religious texts that he and other members of his congregation were composing for use in their missions in monolingual villages in the municipality of Chan Kom. He observed: "It should be in the legitimate Maya language. It cannot be in the Maya of Pisté or in the Maya of [the village of] San Francisco, because these are dialects" (personal communication, August 11, 2004). Here, the only kind of Maya that deserves the title of "language" is that which can be cultivated through special study; what people actually speak today is still a "dialect." The irony here is that the neologisms and hypercorrect phonology implied by this statement would be unfamiliar to the monolinguals in the rural missions, reproducing the ambivalence of Doña Benigna's encounter with "Real Maya."

It is easy to imagine how the kinds of punning and code switching at the heart of Deep Maya tend to be read against this contemporary iteration of Imaginary Maya. Several people from Pisté whom I have interviewed take a special glee in citing a trilingual call of catchers during local baseball games, "Ch'in le bóolao', brooder!," as an example of the poor state of Maya in their community (ch'in is a Maya term that translates roughly to "throw something hard at something else," le boolao' is the Spanish word for ball with Mayan diectical particles, and brooder comes from the English word "brother"). Others, perhaps more prone to appreciate Deep Maya humor, have mentioned the catcher's call to me as a funny example of the ways in which a witty mayero skips between different languages.

Although the association of styles of languaging with social categories remains somewhat fluid in the heteroglossic linguistic sphere of rural Yucatán, there does seem to be some tendency to associate the appreciation of Deep Maya joking with other markers of lower social status. I have often heard friends and informants comment that this type of lively code switching and word play is especially prevalent among woodcarvers and ambulant vendors of artisanry, many of whom come from families at the bottom of the local social hierarchy. As I conducted fieldwork in the area, more than one middle-class informant warned me against picking up Maya from "the artisans," with the observation that their lack of culture was evident from their constant 
vulgar joking and from the fact that they can speak neither Spanish nor Maya well.

\section{CONCLUSION}

The strong historical continuities in language ideologies and social hierarchies that I discuss in this article lead to an obvious question: Have forms of language promotion that emerged in tangent with the post-Cold War wave of indigenous identity movements and multiculturalism necessarily promoted the development new kinds of empowerment and political subjectivity? Contemporary vernacular metalinguistic discourse in rural Yucatán suggests that, even if this latest wave of cultural politics has introduced new elements to national discourses on rights and citizens, the ways in which this is instantiated in the life of rural Maya speakers tends to conform to models of languaging that have deep roots amid the heteroglossia that has been part of this speech community for well over a century. The ways in which these historical substrates influence how contemporary multicultural policies are instantiated in the lives of local communities suggests some ways in which we should rethink both the diverse impacts of multicultural politics and some basic assumptions about the nature of indigenous languages and their speakers.

The official validation of indigenous languages does seem to contribute to positive attitudes toward Maya among the economically better off, persons who might otherwise embrace a language shift to more-prestigious Spanish. However, the parallels between this vernacular purism and philological practices with roots in the 19th century suggests that it is not a "new" kind of political subjectivity associated with emergent minority cultural politics.

Continuities between these local languaging practices and a literary tradition associated with a hispanophone elite leads to a second question: Does the complicity between multicultural discourse and this elitist Imaginary Maya inflict violence on the everyday speech of persons who, because of a lack of formal education or interest, are distanced from this purist register? My example of Doña Benigna and the newscast is just one of many incidents that I have witnessed in which hearing "real" Maya on television and other mass media is not, in and of itself, an empowering experience for native speakers.

But just as contemporary purism reinscribes linguistic hierarchies from above, Deep Maya mockery of hypercorrect speech and writing reinscribes social identities from below. As in my experience on the night when I provided an obsolete term for "moon" suggests, the same Deep Maya interlinguistic play that is used in antagonistic encounters with Spanish speakers can also employ Spanish borrowings and phonetic ambiguities against forms of Maya that are associated with contemporary multicultural politics in Mexico. Making locally valued practices like this style of humor intelligible within the patrimonial discourses of statesponsored language rights entails both a recognition of social and linguistic hierarchies within the Maya language communities and the revision of official assumptions about the nature of "indigenous languages" that have traditionally been suspicions of interlinguistic play.

This said, it is not likely that a greater recognition of the languaging practices that I have referred to as "Deep Maya" could generate a new standard that would work to the exclusion of the purist registers that figure in official language promotion. Even if there is a degree of disconnect between the forms of Maya used in state-sponsored media and the vernacular speech of rural communities, my own experience suggests that the practices that I have referred to as "Deep Maya" are not valued equally by all native speakers and would probably not be a basis for local consensus in developing a "bottom-up" language policy (see Kaplan and Baldauf 1997) that all speakers would prefer over the Imaginary Maya forms of languaging imposed from the top down. In effect, both Deep Maya and Imaginary Maya have deep historical roots and significant contemporary constituencies in rural Yucatan.

One insight that formal language planning could derive from the ethnography and history of vernacular multiculturalisms is a consideration of the presence of the multiple standards existing within speech communities. In rural Yucatán, the social and ethnic identities that represent the substance of post-Cold War cultural politics have historically been indexed through forms of heteroglossia that cannot be reduced to a clear-cut choice between Spanish and Maya. The challenge for educators and language planners is to develop policies in which both Deep and Imaginary Maya are treated as indispensible parts of the local cultural and linguistic heritage whose maintenance is the stated goal of multicultural reforms.

Fernando Armstrong-Fumero Department of Anthropology, Smith College, Northampton, MA 01060

\section{NOTES}

Acknowledgments. The research represented in this article would not have been possible without a great deal of help from friends and colleagues. Besides numerous people in various communities who have been consultants, friends, and gracious hosts over the years, my fieldwork was greatly enriched by dialogue with my colleagues Julio Hoil Gutierrez, Lisa Breglia, Quetzil Castañeda, and Juan Castillo Cocom. Renato Rosaldo, Paulla Ebron, Miyako Inoue, and other faculty mentors at Stanford University also gave me invaluable feedback and support. I am also grateful to colleagues at Smith College and Jocelyn Chua, all of whom gave me feedback on earlier drafts of this article. Special thanks are owed to Ismael May May and Ana Patricia Martinez Huchim, with whom I have had discussions about the state of Maya language media and education that have been important in my work.

1. For discussions of the use of Maya by Yucatecans who are identified as Eurodescendant and nonindigenous in the 19th and 20th century, see Granados y Baeza (1845), Stephens (1963), Zavala (1896). For Mayan influences on Yucatecan Spanish, see Amaro Gamboa (1999).

2. My use of the term languaging in this article is inspired by readings of Mignolo's work and is quite distinct from the function of the same term in the work of the linguist A. L. Becker (1995).

3. In most of Mexico and Latin America, the term mestizo tends to refer to people of mixed indigenous and European genetic and 
cultural heritage. In Yucatán, this term usually refers to people who would be considered "indigenous" in other parts of Mexico (see Gabbert 2004; Redfield and Villa Rojas 1934; Thompson 1974). 4. All other spellings have been in what is referred to as the "official" orthography in Yucatán, a standard based on one developed in Guatemala in the 1980s that is used in most published Mayalanguage in Yucatán today.

5. In one of the latest uses of colonial period texts of which I am aware, the applications for a land grant by the community of Ebtún, filed in 1940, included a carefully transcribed copy of an 18th-century Maya-language title to a contested stretch of bush (see Vecinos de Ebtún 1941).

6. For comparable examples from a Mayan language from Guatemala, see French 2008.

\section{REFERENCES CITED}

Amaro Gamboa, Jesús

1999 Vocabulario del Uayeísmo en la Cultura de Yucatán. Mérida: UADY.

Appadurai, Arjun

1996 Modernity at Large. Minneapolis: University of Minnesota Press.

Bakhtin, Mikhail

1982 The Dialogic Imagination. Austin: University of Texas Press.

Barrera Vasquez, Alfredo

1980 Estudios Linguísticos (Linguistic studies). Mérida: Fondo Editorial Yucatán.

Bartra, Roger

2002 Blood, Ink, and Culture: Miseries and Splendors of the PostMexican Condition. Durham, NC: Duke University Press.

Basso, Keith

1979 Portraits of the Whiteman: Linguistic Play and Cultural Symbols among the Western Apache. Cambridge: Cambridge University Press.

Bauman, Richard, and Charles L. Briggs

2003 Voices of Modernity: Language Ideologies and the Politics of Inequality. Cambridge: Cambridge University Press.

Becker, A. L.

1995 Beyond Translation: Essays Toward a Modern Philology. Ann Arbor: University of Michigan Press.

Bendix, Regina

1997 In Search of Authenticity: The Formation of Folklore Studies. Madison: University of Wisconsin Press.

Berkley, Anthony

1998 Revitalization and Remembrance: The Archive of Pure Maya. Ph.D. dissertation, Department of Anthropology, University of Chicago.

Bonfil Batalla, Guillermo

1987 México Profundo: Una Civilización Negada (Deep Mexico: A civilization denied). Mexico City: Grijalbo.

Breglia, Lisa

2006 Monumental Ambivalence: The Politics of Heritage. Austin: University of Texas Press.

Brinton, Daniel G.

1890 Essays of an Americanist. Philadelphia: Porter and Coates. Brody, Michal

2004 The Fixed Word, the Moving Tongue: Variation in Written Yucatec Maya and the Evolution toward Unified Forms. Ph.D. dissertation, Department of Anthropology, University of Texas at Austin.

Brown, R. McKenna

1996 The Mayan Language Loyalty Movement in Guatemala. In Maya Cultural Activism in Guatemala. Edward Fischer and Robert McKenna Brown, eds. Pp. 165-176. Austin: University of Texas Press.

Burns, Allan

1983 An Epoch of Miracles: Oral Literature of the Yucatec Maya. Austin: University of Texas Press.

Carrillo y Ancona, Cresencio

1950 Los Mayas de Yucatán (The Maya of Yucatan). Mérida: Editorial Yucatense "Club del Libro."

Castañeda, Jorge

1994 Utopia Unarmed: The Latin American Left after the Cold War. New York: Vintage.
Castañeda, Quetzil E.

1996 In the Museum of Maya Culture: Touring Chichén Itzá. Minneapolis: University of Minnesota Press.

2004 "We Are Not Indigenous!": An Introduction to the Maya Identity of Yucatán. Journal of Latin American Anthropology 9(1):36-63.

Castillo Cocom, Juan

2005 "It Was Simply Their Word": Yucatec Maya PRInces in YucaPAN and the Politics of Respect. Critique of Anthropology 25(131):132-155.

Chuchiak, John F.

1997 Intelectuales, los Indios y la Prensa: El Periodismo Polémico de Justo Sierra O'reilly (Intellectuals, Indians and the press: The polemical journalism of Justo Sierra O'Reilly). Saastun 2:3-49.

Cifuentes, Bárbara

2002 Lenguas para un Pasado, Huellas de una Nación: Los Estudios sobre las Lenguas Indígenas de México en el Siglo XIX (Languages for the past, footsteps for a nation: Studies on indigenous languages in Mexico in the 19th century). Mexico City: CONACULTA-INAH.

Durbin, Marshal

1969 An Interpretation of Bishop Diego de Landa's Maya Alphabet. Middle American Research Institute Publications 12:169_ 179.

England, Nora C.

2003 Mayan Language Revival and Revitalization Politics: Linguists and Linguistic Ideologies. American Anthropologist 105(4):733-743.

Fabian, Johannes

1983 Time and the Other: How Anthropology Makes Its Object. New York: Columbia University Press.

Fischer, Ted

1999 Cultural Logic and Maya Identity: Rethinking Constructivism and Essentialism. Current Anthropology 40(4):473499.

Fishman, Joshua

1985 The Rise and Fall of the Ethnic Revival: Perspectives on Language and Ethnicity. Berlin: Mouton.

French, Brigittine M.

2008 Maya Ethnolinguistic Identity: Violence and Cultural Rights in Bilingual Kaqchikel Communities. In Bilingualism and Identity: Spanish at the Crossroads with Other Languages. Mercedes Niño-Murcia and Jason Rothman, eds. Pp. 127-149. Amsterdam: John Benjamins.

Gabbert, Wolfgang

2004 Becoming Maya: Ethnicity and Social Inequality in Yucatán since 1500. Tucson: University of Arizona Press.

Gal, Susan

2001 Linguistic Theories and National Images in NineteenthCentury Hungary. In Languages and Publics: The Making of Authority. Susan Gal and Kathryn Woolard, eds. Pp. 30-45. Manchester: St. Gerome.

Garcia, Maria Elena

2005 Making Indigenous Citizens. Education and Multicultural Development in Peru. Stanford: Stanford University Press.

Garrett, Paul B., and Patricia Baquedano-Lopez

2002 Language Socialization: Reproduction and Continuity, Transformation and Change. Annual Review of Anthropology $31: 339-361$.

Gossen, Gary

1999 Telling Maya Tales: Tzotzil Identities in Modern Mexico. New York: Routledge.

Graham, Laura L.

2002 How Should an Indian Speak? Amazonian Indians and the Symbolic Politics of Language in the Global Public Sphere. In Indigenous Movements, Self-Representation, and the State in Latin America. Kay Warren and Jean E. Jackson, eds. Pp. 181-228. Austin: University of Texas Press.

Granados y Baeza, Fray Bartolomé de

1845 [1813] Los Indios de Yucatán (The Indians of Yucatan). Registro Yucateco I:168-400.

Hale, Charles R.

1994 Between Che Guevara and the Pachamama: Mestizos, Indians and Identity Politics in the Anti-Quincentenary Campaign. Critique of Anthropology 14(1):9-39. 
2005 Neoliberal Multiculturalism: The Remaking of Cultural Rights and Racial Dominance in Central America. PoLAR 28(1):10-28.

Hanks, William

1986 Authenticity and Ambivalence in the Text: A Colonial Maya Case. American Ethnologist 13(4):721-744.

Hernandez, José Juan

1841 Ruinas de Chichén Itzá (Ruins of Chichen Itza). El Museo Yucateco I:270-276.

Hervik, Peter

1999 Mayan People within and beyond Boundaries: Social Categories and Lived Identity in Yucatán. Amsterdam: Harwood Academic.

Hill, Jane

1985 The Grammar of Consciousness and the Consciousness of Grammar. American Ethnologist 12(4):725-737.

1998a Language, Race, and White Public Space. American Anthropologist 100(3):680-689.

1998b Today There Is No Respect: Nostalgia, "Respect," and Oppositional Discourse in Mexicano (Nahuatl) Language Ideology. In Language Ideologies: Practice and Theory. Bambi Schieffelin, Kathryn Woolard, and Paul Kroskrity, eds. Pp. 68-86. Oxford: Oxford University Press.

Hill, Jane, and Kenneth Hill

1986 Speaking Mexicano: Dynamics of Linguistic Syncretism in Central Mexico. Tucson: University of Arizona Press.

Hoil Gutierrez, Julio, Ismael May May, and Patricia Martinez Huchim

2008 Translating, Preserving and Promoting Minority Languages: The Case of Yucatec Maya. Public Presentation at the Louise W. and Edmund J. Kahn Liberal Arts Institute, Smith College, Northampton, November 14.

Humboldt, Wilhelm

1988 [1836] On Language: On the Diversity of Human Language Construction and Its Influence on the Mental Development of the Human Species. Peter Heath, trans. Cambridge: Cambridge University Press.

Jaffe, Alexandra

1996 The Second Annual Corsican Spelling Contest: Orthography and Ideology. American Ethnologist 23(4):816-835.

Kaplan, Robert B., and Richard B. Baldauf

1997 Language Planning from Practice to Theory. Philadelphia: Multilingual Matters.

Lockhart, James

1999 Of Things of the Indies: Essays Old and New in Early Latin American History. Stanford: Stanford University Press.

Keen, Benjamín

1971 The Aztec Image in Western Thought. New Brunswick, NJ: Rutgers University Press.

Makihara, Miki

2004 Linguistic Syncretism and Language Ideologies: Transforming Sociolinguistic Hierarchy on Rapa Nui (Easter Island). American Anthropologist 106(3):529-540.

Maxwell, Judith M

1996 Prescriptive Grammar and Kaqchikel Revitalization. In Maya Cultural Activism in Guatemala. Edward Fischer and Roy McKenna Brown, eds. Pp. 178-194. Austin: University of Texas Press.

Mediz Bolio, Antonio

1934 La Tierra del Faisán y del Venado (Land of the pheasant and the deer). Mexico City: Editorial México.

Mignolo, Walter

1995 The Darker Side of the Renaissance: Literacy, Territoriality, and Colonization. Ann Arbor: University of Michigan Press.

2000 Local Histories/Global Designs: Coloniality, Subaltern Knowledges, and Border Thinking. Princeton: Princeton University Press.

Paulston, Christina Bratt

1997 Language Policies and Language Rights. Annual Review of Anthropology 26:73-85.

Pfeiler, Barbara, and Lenka Zámisiá

2006 Bilingual Education: Strategy for Language Maintenance or Language Shift of Yucatec Maya? In Mexican Indigenous Languages at the Dawn of the Twenty-First Century. Margarita Hidalgo, ed. Pp. 281-300. Berlin: Mouton de Gruyter.
Redfield, Robert, and Alfonso Villa Rojas

1934 Chan Kom: A Maya Village. Washington, DC: Carnegie Institution of Washington.

Restall, Mathew

1997 Heirs to the Hieroglyphs: Indigenous Writing in Colonial Mesoamerica. The Americas 54(2):239-267.

Schieffelin, Bambi

2000 Introducing Kaluli Literacy: A Chronology of Influences. In Regimes of Language. Paul V. Kroskrity, ed. Pp. 293-328. Santa Fe: School of American Research Press.

Schieffelin, Bambi B., and Rachelle Charlier Doucet

1994 The "Real" Hatian Creole: Ideology, Metalinguistics and Orthographic Choice. American Ethnologist 21(1):176-200.

Silverstein, Michael

2000 Whorfianism and the Linguistic Imagination of Nationality. In Regimes of Language. Paul V. Kroskrity, ed. Pp. 85-137. Santa Fe: School of American Research Press.

Stephens, John L.

1963 [1843] Incidents of Travel in Yucatan, vol. 2. New York: Dover.

Sullivan, Paul R.

1989 Unfinished Conversations: Mayas and Foreigners between Two Wars. New York: Knopf-Random House.

Thompson, Richard Allen

1974 The Winds of Tomorrow: Social Change in a Maya Town. Chicago: University of Chicago Press.

Urla, Jacqueline

1988 Ethnic Protest and Social Planning: A Look at Basque Language Revival. Cultural Anthropology 3(4):379-394.

Vecinos de Ebtún

1941 Letter to the Mixed Agrarian Comission. Ebtun File, exp 155. Registro Agrario Nacional. Mérida, Yucatán, Mexico.

Villoro, Luis

1950 Los Grandes Momentos del Indigenismo en México (Great moments in Mexican indigenism). Mexico City: Colegio de México.

Warman, Arturo, ed.

1967 Eso Que Llaman la Antropología Mexicana (That which they call Mexican anthropology). Mexico City: Nuestro Tiempo.

Warren, Kay

1998 Indigenous Movements and Their Critics: Pan-Maya Activism in Guatemala. Princeton: Princeton University Press.

Warren, Kay, and Jean E. Jackson

2002 Introduction: Studying Indigenous Activism in Latin America. In Indigenous Movements, Self-Representation, and the State. Kay Warren and Jean Jackson, eds. Pp. 1-45. Austin: University of Texas Press.

Williams, Raymond

1973 The Country and the City. New York: Oxford University Press.

Woolard, Kathryn A.

1998 Introduction: Language Ideology as a Field of Inquiry. In Language Ideologies: Practice and Theory. Bambi Schieffelin, Kathryn Woolard, and Paul Kroskrity, eds. Pp. 3-47. Oxford: Oxford University Press.

Woolard, Kathryn A., and Bambi Schieffelin

1994 Language Ideology. Annual Review of Anthropology 23:5582.

Yashar, Deborah J.

2005 Contesting Citizenship in Latin America: The Rise of Indigenous Movements and the Postliberal Challenge. Cambridge: Cambridge University Press.

Zavala, Miguel

1896 Gramática Maya (Mayan grammar). Mérida: Imprenta de le Ermita.

\section{FOR FURTHER READING}

(These selections were made by the American Anthropologist Editorial Interns as examples of research related in some way to this article. They do not necessarily reflect the views of the author.) 
Adams, Abigail E.

2003 Mayan Visions: The Quest for Autonomy in an Age of Globalization. American Ethnologist 30(1):182-183.

Barrett, Rusty

2008 Linguistic Differentiation and Mayan Language Revitalization in Guatemala. Journal of Sociolinguistics 12(3):275305.

Hale, Charles R

2006 Activist Research v. Cultural Critique: Indigenous Land Rights and the Contradictions of Politically En- gaged Anthropology. Cultural Anthropology 21(1):96120.

Mora-Marín, David F.

2003 Historical Reconstruction of Mayan Applicative and Antidative Constructions. International Journal of American Linguistics 69(2):186-228.

Nelson, Diane M.

2001 Indian Giver or Nobel Savage: Duping, Assumptions of Identity, and Other Double Entendres in Rigoberta Menchú Tum's Stoll/En Past. American Ethnologist 28(2):303-331. 